\title{
Sistem Pendukung Keputusan Pemilihan Tempat Kuliner di Depok dengan TOPSIS
}

\author{
Avriana Indarwasti, Barizana S.A, Prottasof G.K \\ Program Studi Teknik Informatika \\ Jurusan Teknik Informatika dan Komputer \\ Politeknik Negeri Jakarta \\ avrianana@gmail.com, sbarizana@gmail.com,pottakodu@gmail.com
}

Diterima: 25 Maret 2017. Disetujui: 10 April 2017. Dipublikasikan: Mei 2017

\begin{abstract}
Abstrak - Untuk mendapatkan informasi mengenai tempat kuliner di Depok yang sesuai dengan kebutuhan keinginan masih banyak konsumen yang bingung. Karena itu dibuat suatu sistem informasi kuliner berbasis website. Digunakan TOPSIS yang dapat melakukan perangkingan menurut kelebihan tempat kuliner dengan kriteria yang sama. Kriteria penilaian yang digunakan adalah rasa, variasi menu, waktu operasional, area dan fasilitas dimana tiap kriteria akan diberikan bobot. Hasil yang diperoleh dari penelitian ini adalah alternatif saran atau pilihan tempat kuliner terbaik. Dari hasil perhitungan dengan menggunakan TOPSIS didapatkan tempat kuliner WP menempati urutan pertama dengan nilai preferensi relatif untuk setiap alternatifnya sebesar 0,77 . OTW menempati urutan kedua, dengan nilai preferensi relatifnya adalah 0,66. WU sebagai urutan ketiga dengan nilai preferensi relatif 0,63 .
\end{abstract}

Kata Kunci: sistem pendukung keputusan (SPK), TOPSIS, kuliner.

\section{PENDAHULUAN}

Wisata kuliner, boleh jadi menjadi salah satu alasan tersendiri, yang menyebabkan orang-orang tertarik untuk dapat berkunjung dan berpindah tempat yang jauh sekalipun untuk tempat kuliner berbeda. Selain teknologi yang berkembang dan tumbuh mengikuti jaman, kuliner juga terpengaruh. Sehingga perekonomian lokal juga dapat dipengaruhi dalam sisi positif, karena semakin orang-orang memiliki inovasi baru, makin besar wisata kuliner berkembang.

Untuk meningkatkan jumlah kunjungan wisatawan, pembangunan infrastruktur dan sinergi antar Satuan Organisasi Tata Kerja (SOTK) telah menjadi satu hal yang diperhatikan Pemerintah Kota Depok. Di Kota Depok wisata kuliner dan fashion sangat penting didukung oleh sektor infrastruktur karena wisata kuliner dan fashion yang makin diminati di Kota Depok. Diharapkan dengan adanya pembangunan infrastruktur dan sarana prasarana pendukung tempat obyek wisata di Kota Depok menjadi dapat lebih dikenal seluruh masyarakat dan layak untuk dikunjungi.

Saat ini wisatawan tertarik datang ke Kota Depok hanya untuk menikmati kuliner dan fashion. Bagian di Depok yang paling lengkap adalah di sepanjang Jalan Margonda Raya yang sudah banyak terdapat restoran, mall, dan outlet-outlet fashion. Daerah Margonda kini menjadi objek kuliner utama di daerah Depok dengan jenis, keunikan, rasa, dan fasilitas yang disajikan berbeda dari setiap tempat kuliner tersebut. Apalagi Margonda dikelilingi beberapa perguruan tinggi, maka mahasiswa yang memiliki waktu senggang menunggu jadwal kuliah ataupun ingin mengerjakan tugas kuliah akan menjadikan tempat kuliner yang memiliki fasilitas wifi dan stop contact serta makanan yang bercita rasa enak akan dipilih oleh wisatawan. Dengan tagline Depok yang berupa "Depok a Friendly City", pemerintah akan terus berusaha menjadikan wisatawan sebagai sahabat sehingga wisatawan yang datang ke Kota Depok akan terasa nyaman dan unggul dalam bidang wisata.

\section{TINJAUAN PUSTAKA}

\section{A. Kuliner}

Culinary dalam bahasa Inggris berarti hal yang berhubungan dengan dapur dan juga dengan keahlian masak-memasak. Dalam bahasa Indonesia disebut dengan kata kuliner. Menurut [1] "Kuliner adalah hasil olahan yang berupa masakan, masakan tersebut berupa lauk-pauk, makanan (panganan) dan minuman". Dengan menarik kesimpulan diatas dapat disimpulkan 
bahwa kuliner adalah hasil olahan yang berupa masakan. Masakan tersebut berupa lauk pauk, makanan (penganan), dan minuman. Karena setiap daerah memiliki cita rasa tersendiri, maka tak heran jika setiap daerah memiliki tradisi kuliner yang berbeda-beda. Kuliner merupakan sebuah gaya hidup yang tidak dapat dipisahkan. Karena setiap orang memerlukan makanan yang sangat dibutuhkan seharihari, mulai dari makanan yang sederhana hingga makanan yang berkelas tinggi dan mewah.

\section{B. Sistem Pendukung Keputusan (SPK)}

Sistem pendukung keputusan (decision support systems) disingkat DSS, adalah bagian dari sistem informasi berbasis komputer (termasuk sistem berbasis pengetahuan (manajemen pengetahuan) yang dipakai untuk mendukung pengambilan keputusan dalam suatu organisasi atau perusahaan. Dapat juga dikatakan sebagai sistem komputer yang mengolah data menjadi informasi untuk mengambil keputusan dari masalah semi-terstruktur yang spesifik. SPK dapat digambarkan sebagai sistem yang berkemampuan mendukung analisis ad hoc data, dan pemodelan keputusan, berorientasi keputusan, orientasi perencanaan masa depan, dan digunakan pada saat-saat tidak biasa. Tujuan dari SPK:

- Membantu menyelesaikan masalah semiterstruktur

- Mendukung manajer dalam mengambil keputusan suatu masalah

- Meningkatkan efektifitas bukan efisiensi pengambilan keputusan

Dalam pemrosesannya, SPK dapat menggunakan bantuan dari sistem lain seperti Artificial Intelligence, Expert Systems, Fuzzy Logic, dll.

\section{Metode TOPSIS}

Technique for Order Preference by Similarity to Ideal Solution (TOPSIS) didasarkan pada konsep dimana alternatif terpilih yang terbaik tidak hanya memiliki jarak terpendek dari solusi ideal positif, namun juga memiliki jarak terpanjang dari solusi ideal negatif [2]. TOPSIS adalah metode multi kriteria yang digunakan untuk mengidentifikasi solusi dari himpunan alternatif berdasarkan minimalisasi simultan dari jarak titik ideal dan memaksimalkan jarak dari titik terendah. TOPSIS dapat menggabungkan bobot relatif dari kriteria penting [3]. TOPSIS banyak digunakan dengan alasan:

- Konsepnya sederhana dan mudah dipahami;

- Komputasinya efisien;
- Memiliki kemampuan untuk mengukur kinerja relatif dari alternatif-alternatif keputusan dalam bentuk matematis yang sederhana;

Langkah-langkah penyelesaian masalah MADM dengan TOPSIS [4]:

- Membuat matriks keputusan yang ternormalisasi;

- Membuat matriks keputusan yang ternormalisasi terbobot;

- Menentukan matriks solusi ideal positif \& matriks solusi ideal negatif;

- Menentukan jarak antara nilai setiap alternatif dengan matriks solusi ideal positif \& matriks solusi ideal negatif;

- Menentukan nilai preferensi untuk setiap alternatif [5].

\section{PERANCANGANDAN REALISASI}

\section{A. Desain Sistem}

Pada sistem Eatgasm terlihat bahwa user melalui web browser meminta informasi yang terdapat pada website. Web server akan melayani permintaan tersebut dengan mengambil data-data dari database yang dibutuhkan dan akan mengirimkan balasan berupa informasi yang diminta.

B. Perancangan Sistem

Sistem Website Eatgasm akan digambarkan dengan secara jelas di Gambar 1. Terdapat dua aktor yaitu admin dan user. Gambar 2 adalah dari Use Case pada sistem Website Eatgasm.

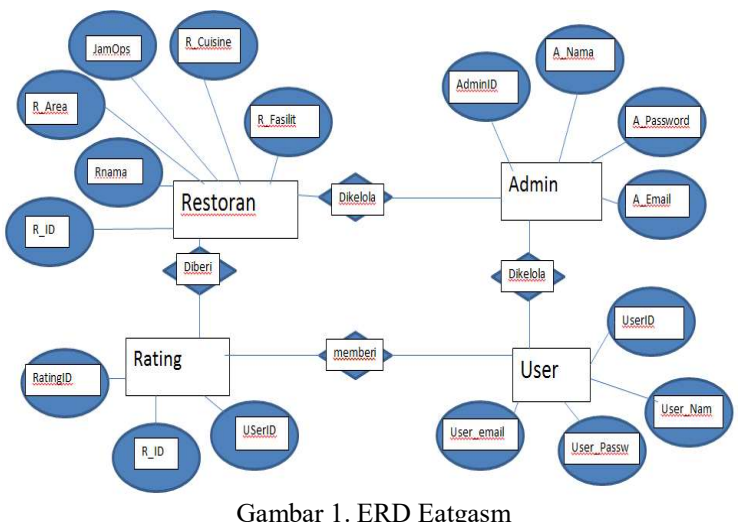

\section{Desain Website Eatgasm}

Pada pembuatan website Eatgasm ini terdapat Homepage beserta dengan menu dan fitur lainnya yang terdapat pada website ini. Website Eatgasm ini dibuat agar user friendly. Pembuatan website ini 
menggunakan Visual Studio dan CSS. Gambar 3 adalah tampilan Homepage realisasi dari Website Eatgasm.

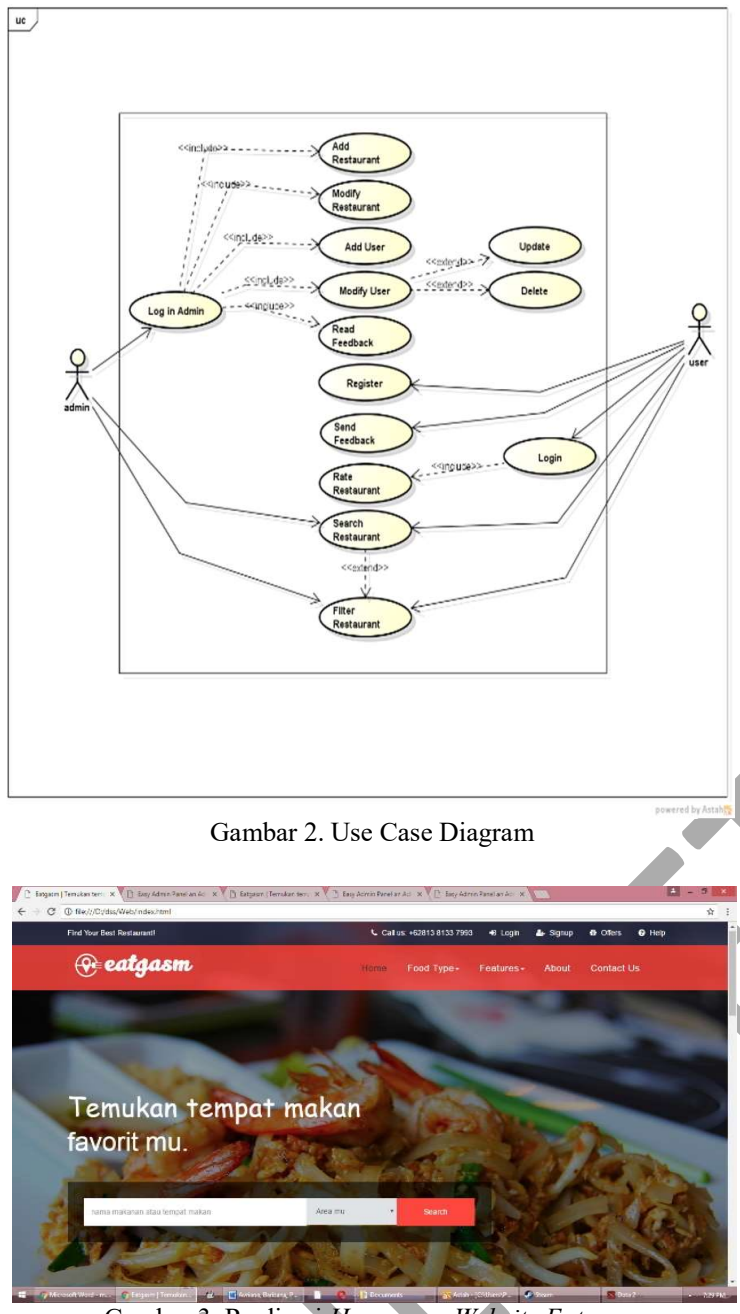

Gambar 3. Realisasi Homepage Website Eatgasm

\section{PENGUJIAN DAN ANALISA}

A. Pengujian Sistem Website Eatgasm

Pada bab ini akan dibahas mengenai pengujian dari Website Eatgasm yang sudah dibuat. Hal ini dibuat bertujuan untuk mengetahui sejauh mana ketepatan website bisa berjalan serta tidak menutup kemungkinan dapat mengetahui kelemahannya. Sehingga dari sini nantinya dapat disimpulkan apakah perangkat lunak yang dibuat dapat berjalan dengan benar dan sesuai dengan kriteria yang diharapkan:

Ditampilkan hasil pengujian pada fitur pencarian. Pencarian adalah proses dimana user mengisi kriteria restaurant yang ingin di kunjungi. Pada halaman ini akan tersedia beberapa restoran yang sudah di filter dengan DSS. Halaman pencarian seperti yang terlihat pada Gambar 4 .

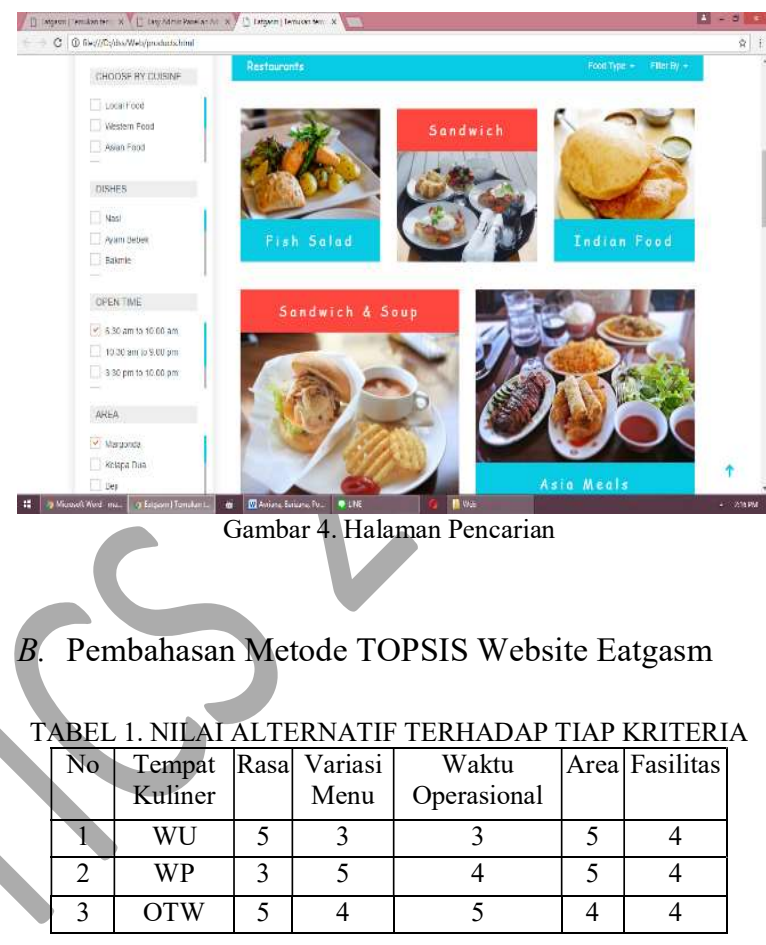

1) Menentukan matriks keputusan ternomalisasi. Dalam menentukan matriks keputusan ternormalisasi, nilai tiap kriteria (xij) untuk keseluruhan alternatif dijumlahkan kemudian nilai masing-masing kriteria tersebut dibagi dengan hasil jumlah kriterianya.

Untuk kriteria rasa $(\mathrm{C} 1)$

$$
\begin{aligned}
& |\mathrm{C} 1|=\sqrt{(5)^{2}+(3)^{2}+(5)^{2}} \\
& =7,68 \\
& \mathrm{R} 11=\mathrm{X} 11 / \mathrm{C} 1=5 / 7,68=0,65 \\
& \mathrm{R} 21=\mathrm{X} 21 / \mathrm{C} 1=3 / 7,68=0,39 \\
& \mathrm{R} 31=\mathrm{X} 31 / \mathrm{C} 1=5 / 7,68=0,65
\end{aligned}
$$

Untuk kriteria variasi menu $(\mathrm{C} 2)$

$$
\begin{aligned}
& \mathrm{C} 1 \mid=\sqrt{(3)^{2}+(5)^{2}+(4)^{2}} \\
& =7,07 \\
& \mathrm{R} 11=\mathrm{X} 11 / \mathrm{C} 2=3 / 7,07=0,42 \\
& \mathrm{R} 21=\mathrm{X} 21 / \mathrm{C} 2=5 / 7,07=0,71 \\
& \mathrm{R} 31=\mathrm{X} 31 / \mathrm{C} 2=4 / 7,07=0,57
\end{aligned}
$$

Dan seterusnya, hingga didapatkan Tabel 2. 
TABEL 2. MATRIK TERNORMALISASI (R)

\begin{tabular}{|l|l|l|l|l|}
\hline 0,65 & 0,42 & 0,42 & 0,66 & 0,58 \\
\hline 0,39 & 0,71 & 0,57 & 0,55 & 0,58 \\
\hline 0,65 & 0,57 & 0,71 & 0,15 & 0,58 \\
\hline
\end{tabular}

2) Menentukan matriks keputusan normalisasi terbobot.

Sebelum menghitung matriks keputusan normalisasi terbobot, tentukan terlebih dahulu bobot dari masing-masing kriteria. Tingkat kepentingan tiap kriteria dapat dinilai dari range 1 sampai 5, yaitu:

1 : tidak penting

2 : tidak terlalu penting

3 : cukup penting

4 : penting

5 : sangat penting

Nilai bobot awal (w) digunakan untuk menunjukkan tingkat kepentingan relatif dari setiap kriteria. Setelah menentukan bobot dari masing-masing kriteria, maka berdasarkan langkah 1 dan persamaan 2, dapat menghitung matriks normalisasi terbobot yaitu: $\mathrm{Y}=\mathrm{Rij} \times \mathrm{W}$

TABEL 3. NORMALISASI TERBOBOT

\begin{tabular}{|r|r|r|r|r|}
\hline $\mathrm{S}$ & 1,26 & 1,26 & 2,64 & 2,9 \\
\hline 1,95 & 2,13 & 1,71 & 2,2 & 2,9 \\
\hline 3,25 & 1,71 & 2,13 & 0,6 & 2,9 \\
\hline
\end{tabular}

3) Menentukan matriks solusi ideal positif dan matriks solusi ideal negatif

Matrik solusi ideal positif $(\mathrm{A}+)$ :

$\mathrm{Y}_{1}{ }^{+}=\operatorname{MAX}(3,25,1,95,3,25)=3,25$

$\mathrm{Y}_{2}{ }^{+}=\operatorname{MAX}(1,26,2,13,1,71)=2,13$

$\mathrm{Y}_{3}{ }^{+}=\operatorname{MAX}(1,26,1,71,2,13)=2,13$

$\mathrm{Y}_{4}^{+}=\operatorname{MAX}(2,64,2,22,0,6)=2,64$

$\mathrm{Y}_{5}{ }^{+}=\operatorname{MAX}(2,9,2,9,2,9)=2,9$

$\mathrm{A}^{+}=(3,25,2,13,2,13,2,64,2,9)$

Solusi ideal negatif dihitung sebagai berikut :

$\mathrm{Y}_{1}=\operatorname{MIN}(3,25,1,95,3,25)=1,95$

$\mathrm{Y}_{2}=\mathrm{MIN}(1,26,2,13,1,71)=1,26$

$\mathrm{Y}_{3}{ }^{-}=\operatorname{MIN}(1,26,1,71,2,13)=1,26$

$\mathrm{Y}_{4}=\mathrm{MIN}(2,64,2,22,0,6)=0,6$

$\mathrm{Y}_{5}{ }^{-}=\mathrm{MIN}(2,9,2,9,2,9)=2,9$

$\mathrm{A}^{+}=(1,95,1,26,1,26,0,6,2,9)$

Demikian seterusnya, terakhir diperoleh solusi ideal positif dan solusi ideal negatif:
TABEL 4. MATRIKS SOLUSI IDEAL POSITIF DAN NEGATIF

\begin{tabular}{|l|c|c|c|c|c|}
\hline & Y1 & Y2 & Y3 & Y4 & Y5 \\
Solusi Ideal (+) & 3,25 & 2,13 & 2,13 & 2,64 & 2,9 \\
Solusi Ideal (-) & 1,95 & 1,26 & 1,26 & 0,6 & 2,9 \\
\hline
\end{tabular}

4) Menentukan jarak antara nilai setiap alternatif dengan matriks solusi ideal positif \& matriks solusi ideal negatif

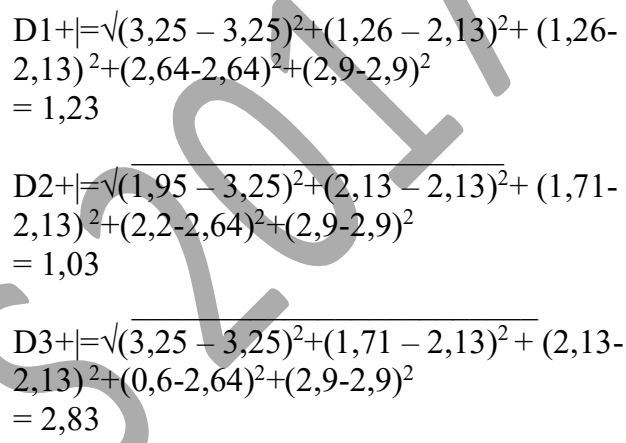

Jarak antara alternatif A, dengan solusi ideal negatif dirumuskan sebagai:

$$
\begin{aligned}
& \text { D1- }=\sqrt{(3,25-1,95)^{2}+(1,26-1,26)^{2}+}(1,26- \\
& 1,26)^{2}+(2,64-0,6)^{2}+(2,9-2,9)^{2} \\
& =2,42 \\
& \text { D2- }=\sqrt{(1,95-1,95)^{2}+(2,13-1,26)^{2}}+(1,71- \\
& 1,26)^{2}+(2,2-0,6)^{2}+(2,9-2,9)^{2} \\
& =3,52 \\
& \text { D3-| }=\sqrt{(3,25-1,95)^{2}+(1,71-1,26)^{2}+}(2,13- \\
& 1,26)^{2}+(0,6-0,6)^{2}+(2,9-2,9)^{2} \\
& =1,63
\end{aligned}
$$

5) Langkah terakhir dalam perhitungan TOPSIS adalah mencari nilai preferensi untuk setiap alternatif diberikan.

Nilai Vi yang lebih besar menunjukan bahwa alternatif $\mathrm{Ai}$ lebih dipilih. Menghitung nilai preferensi:

$\mathrm{V} 1=2,42 / 1,23+2,42=0,66$

$\mathrm{V} 2=3,52 / 1,03+3,52=0,77$

$\mathrm{V} 3=2,83 / 2,83+1,63=0,63$

Tabel 5 merupakan hasil perhitungan nilai preferensi untuk semua alternatif. 
TABEL 5. NILAI PREFERENSI SETIAP ALTERNATIF

\begin{tabular}{|c|l|c|}
\hline $\mathrm{V} 1=$ & 0,66 & $\mathrm{WU}$ \\
\hline $\mathrm{V} 2=$ & 0,77 & $\mathrm{WP}$ \\
\hline $\mathrm{V} 3=$ & 0,63 & OTW \\
\hline
\end{tabular}

Berdasarkan nilai preferensi terbesar 0,77 maka tempat kuliner WP adalah tempat kuliner yang paling direkomendasikan.

\section{PENUTUP}

\section{A. Kesimpulan}

Berdasarkan pembahasan yang dilakukan dalam penelitian, maka dapat diambil kesimpulan yaitu:

a. Aplikasi yang sudah dibuat memberikan suatu rekomendasi alternatif keputusan tempat kuliner di kota Depok berdasarkan kriteria rasa, variasi menu, waktu operasional, area dan fasilitas, menggunakan Metode TOPSIS.

b. Hasil dari perhitungan dengan menggunakan TOPSIS didapatkan tempat kuliner WP menempati urutan pertama dengan nilai preferensi relatif untuk setiap alternatifnya sebesar 0,77. OTW menempati urutan kedua, dengan nilai preferensi relatifnya adalah 0,66. Dengan WU sebagai urutan ketiga dengan nilai preferensi relatif 0,63 .

\section{B. Saran}

Berdasarkan kesimpulan yang telah dikemukakan, maka diajukan saran untuk penelitian selanjutnya, yaitu: Sistem informasi ini hanya dapat menambahkan tempat kuliner yang dimasukkan oleh admin. Sebaiknya, pemilik tempat kuliner dapat menambahkan tempatnya sendiri dengan melakukan registrasi seperti user.

\section{REFERENSI}

[1] Shoim, Yulia dkk. 2017. Kuliner dan Fashion Depok Diminati Wisatawan. http://www.depok.go.id/04/01/2017/01-beritadepok/kuliner-dan-fashion-depok-diminati-wisatawan

[2] Sepayung, Sandy. 2014. Sistem Pendukung Keputusan Metode TOPSIS \& Contoh Implementasi. $\mathrm{http}: / /$ www.academia.edu/31852759/SISTEM PENDUKUNG KEPUTUSAN Metode TOPSIS and Contoh Implementasi

[3] Kurniati, Ulfi. 2016. Sistem Pendukung Keputusan Pemilihan Tempat Stand Pameran Dengan Menggunakan Metode TOPSIS. Malang: Jurnal STT STIKMA Internasional

[4] Dahniar, Rossalie. sistem penunjang keputusan pemilihan tempat kuliner berbasis web menggunakan metode TOPSIS beserta informasi geografis di kota Malang. Malang.

[5] Marsono, Ahmad Fitri Boy, dan Wulan Dari. 2015, Sistem Pendukung Keputusan Pemilihan Menu Makanan pada Penderita Obesitas dengan Menggunakan Metode TOPSIS (Studi Kasus di RS Siti Rahma Tanjung Morawa). Medan Jurnal SAINTIKOM. 